\title{
Priming human-computer interactions: Experimental evidence from economic development mobile surveys
}

\section{Kweku Opoku-Agyemang $\dagger$}

This paper investigates how citizens from developing countries vocalize controversial topics, combining the behavioral economics of development with human-computer interaction for potentially mutual benefit across fields. I examine a priming effort to understand how people decide to discuss controversial local subjects, using the human-computer interaction of people with their mobile phones to quantify how attracted people feel to alternative local political economy topics when randomly asked what they think about international aid. The treatment significantly impacted the likelihood of choosing to discuss sanitation, health, poverty, democracy, individual determination, pro-poor support, and happiness. However, the intervention does not affect subjectively ranked preferences. The proposed approach quantifies the attraction users feel to concepts based on human-computer interactions and this approach may be relevant for contexts beyond developing countries. Human-computer interaction approaches may help policy makers entrusted with the Sustainable Development Goals and other initiatives better understand the needs and desires of people in developing countries.

$\dagger$ Postdoctoral Research Associate, Cornell Tech, New York, NY 10011, USA and Honorary Research Fellow, Center for Effective Global Action, Department of Agricultural and Resource Economics, University of California, Berkeley, Berkeley, CA 94720, USA. Email: kweku@ berkeley.edu.

Acknowledgments: I am very grateful to participants of the Africa Table Lecture Series at Stanford University's Center for African Studies and the Development Impact Lab's Research in Action Series at the University of California, Berkeley, for helpful feedback. I thank Kobina Otoo, Levi Goertz and Louis Dorval and VOTO Mobile for excellent assistance while doing this research. This research was funded by the National Science Foundation under Grant No. IIS-1054332. This work was supported by the Development Impact Lab (USAID Cooperative Agreements AID-OAA-A-13-00002 and AID-OAA-A12- 00011) and the Blum Center for Developing Economies, University of California, Berkeley. The author alone, and not any organization or entity, is responsible for all content in this article. 


\section{Introduction}

One of the major hurdles facing the social sciences and policy making is the problem of research transparency (Ioannidis, 2005). Recent research has drawn attention to the need for research accountability in the studies of self-reported preferences in the behavioral sciences (Casey, Glennerster \& Miguel, 2012; Miguel et al, 2014; Nosek et al, 2015; Camerer et al, 2016). Whether or not primes or "nudges" consistently affect preferences with respect to important social issues is unclear and even controversial, given the common failure of much survey evidence to replicate (Harris, Coburn, Rohrer, \& Pashler, 2015; Cesario, 2014). Improved measurement may be one way to improve our understanding of development: a parallel literature on human-computer interaction at the intersection of computer science and international development (Aker, Ghosh \& Burrell, 2016) shows how citizens in developing countries interact with technologies. Given that human-computer interactions are usually based on observed (and not self-reported) data, this perspective could help social science and development research become more transparent and better understand behavioral outcomes beyond self-reported surveys. In spite of the rise of mobile telephony and behavioral economics in development studies, human-computer interaction has not yet been extended to analyze priming in this space, even though it could provide policy makers with an improved view of the preferences and decisions that people in developing countries make on a regular basis.

In this paper, I compare the self-ranked surveyed preferences commonly used in the behavioral economics of development with a human-computer interaction approach of gauging preferences. I use automated mobile survey experiments based on a mobile survey platform as a way to commit to transparency. By focusing on how citizens interact with their phones as a way of gauging their preferences, the paper also shows how human-computer interaction can complement self-reported ranked preferences. In so doing, I bring some complexity to the ongoing discourse on whether primes significantly impact behavior. My result is that a randomized prime may motivate individuals to gravitate towards certain topics, even if their selfreported ranked preferences are not significantly affected. This paper asks whether stimulating citizens to think about international aid affects how they navigate their phones to discuss controversial localized governance topics. I hypothesize that such topics exert a sort of psychological gravitational pull or cognitive attraction on citizens in a similar way to how economists and social scientists think of trade (Donaldson, 2017) and migration (Mayda, 2010) as having gravitational characteristics in the economy. The evidence is based on mobile survey experiments performed in Ghana to test the theory. Even though the paper is the first to present a mobile survey human-computer experiment in the behavioral science space, the deliberate engineering of ambiguous mediated communication and the use of ambiguous allocation rules is 
broadly in line with recent research (Bose \& Renou, 2014). By focusing on how agents gravitate towards alternative choices, my approach provides empirical backing to the willpower explanations of how decisions manifest in behavioral science (Phelps \& Pollak, 1968; Gul \& Pesendorfer, 2001; Laibson, 1997). My human-computer interaction approach and findings also yield a compromise to the question on whether subjective well-being is a rigid (Brickman \& Campbell, 1971; Easterlin, 1974) or flexible (Lyubomirsky, Sheldon, \& Schkade, 2005; Niven, Totterdell, Holman, \& Headley 2012) phenomenon.

The application studied in the paper is the topic of international aid and local governance, which I find relevant for the discourse on priming. One major problem which hampers the efficiency of democratic governance is communication (Downs, 1957). Democracy depends on people engaging with and discussing issues that may be controversial in developing countries. However, it is unclear how to foster such engagement without disregarding sociocultural norms and potentially violating the ethos of democracy itself. Although international aid is a complex endeavor (Qian, 2015), one major concern is that the voices of the global poor are underrepresented in global development policy discussions as well (Holland, Blackburn, \& Chambers, 1998; Johnson, 2001; Taylor, 2011). This outcome starkly contrasts with vibrant discussions on international aid from researchers (Sachs, 2006; Easterly, 2001; Easterly 2006; Nunn \& Qian, 2014). This gap exists in spite of the critical importance of inclusion in improving development outcomes (Acemoglu \& Robinson, 2012), the potential role of technology access in social outcomes (Bauernschuster, Falck, \& Woessmann, 2014) and the importance of democratic political reform in Ghana (Gyimah-Boadi, 2009).

There are signs that the absence of citizen involvement in international aid processes and the lack of local democratic engagement are related. For example, an inadequate understanding of local citizen preferences may hinder international development projects from gaining traction in host communities and or cause harm when inappropriate projects are adopted ( $\mathrm{Li}, 2007$; Mitchell, 2002). The question of where citizen preferences for development issues originate have received relatively little research attention.

Previous research implies that political economy preferences are often rooted in organized thought patterns that categorize information-based relationships (Laitin \& Wildavsky, 1988). Unfortunately, poverty may in of itself influence cognitive mechanisms and serve as a barrier to unpacking such information (Mani, Mullainathan, Shafir \& Zhao 2013). Emerging work is showing the potential influence of surveys in accessing such processes (Kimball, 2015). In particular, policy makers are realizing that the mobile phones that are increasingly common in developing countries may help such data collection in general (Tomlinson, 2009) and poverty studies in particular (Blumenstock, Cadamuro \& On, 2015). Important research using SMS (short message services) has found that Ugandan elites may prefer governmental programs over 
aid, whereas citizens may prefer aid to national programs (Findley et al, 2015). Recent work shows that mobile surveys system used in this paper provides statistically representative, robust and reliable results in African country contexts (Leo et al, 2015). In the human-computer interaction literature, work also shows that commitments to computers may be more reflective of individual engagement than when people interact with other humans (Posard and Rinderknecht, 2015), although our understanding of human engagement with interfaces is still evolving. In particular, it is relatively unclear how to map such interactions with socioeconomic preferences.

My study brings these discussions together. I conduct a mobile phone survey experiment, using a simple randomized controlled trial to bridge global and national political economy preferences using voice-based surveys. The data is from a software solution based in Ghana called VOTO Mobile. This mobile survey platform has assisted the data collection efforts of the United Nations, Cowater International, Innovations for Poverty Action, Facebook and other policy stakeholders (VOTO Mobile, 2014). Relative to SMS, voice-based surveys may be relatively suited for doing survey experiments and impact evaluations in developing countries representatively, particularly in rural areas where literacy abilities may be wanting. VOTO Mobile provided no input into the design of the research program.

This minimalist research approach is also motivated by the experimental observation that surveys impact research participant estimates in and of themselves (Zwane et al, 2014). Although such tendencies are relevant for all survey methodologies, such behavioral biases may particularly hold for surveys done via mobile phone. As such, surveying individuals on multiple occasions for background variables to inform randomization would therefore bias estimates, being primes of their own. To minimize these concerns, I instead exclusively on treatments and outcomes with the benefit of the blinded randomization process.

The uniquely-administered voice surveys have benefits for the randomization process. The automated randomization process is beyond the control of the researcher, based on an algorithm that is optimized to select randomly from all mobile phones in use throughout Ghana. Missed calls are tried while optimizing for transcending network congestion and acknowledging times when participants are away from their mobile phones to allow for surveys to be completed at times that are convenient. Voice surveys are performed and recorded in any of the most-spoken languages in Ghana (Twi, Hausa, Ewe, Dagomba and English, the official language) with subjects' permission. The VOTO Mobile process may also minimize experimenter effects, which may occur when researchers are able to unconsciously influence study participants. This issue is minimized in this case, as an automation process "assigns" treatment and control units in a "hands-free" process. Any expected differences may be expected to significantly fall with large sample sizes (Bruhn and McKenzie, 2009). 
One potential explanation for the observation of preference gravitation and the absence of self-reported preference impacts is that there may be a gap between shifts in mental associations and self-reported preferences. Although much of the social psychology literature asks whether nudges affect preferences, this depends to some extent on whether the prime allows one to gravitate to one topic relative to another.

Although economists have long been aware of the importance of functional forms (Leamer, 1983), most recent work in program evaluation has stressed evaluation design (Angrist \& Pischke, 2010) and relevant data collection innovations (Kuziemko, Norton, Saez, \& Stantcheva 2015). In the paper, I also test whether the experimental results are robust to relaxing standard functional form assumptions and estimations. I use Kernel Regularized Least Squares (KRLS) estimation, a machine learning approach (Hainmueller \& Hazlett, 2013) which constructs algorithms that learn from data, merging these with a randomized experimental set-up. In so doing, the paper answers the call for work showing how statistical prediction approaches can support causal inference (Einav \& Levin, 2014; Varian, 2014; Athey, 2017). The findings also builds work that theorizes an attraction effect (Ok \& Riella, 2015), building on other work that theorizes a value of preferences (Bartling, Fehr \& Herz, 2014). The divergence between a measured preference and a known preference may reflect from errors from self-reporting (Cason \& Plott, 2014).

\section{Field Work and Data Collection}

The mobile survey was supported by in-person field studies in Ghana's Central and Greater Accra Regions. These areas host the respective former and present Ghanaian capitals and are hence representative in terms of socioeconomic diversity. The main treatment questions were finalized after several semi-structured interviews with citizens on poverty and development in their lived experiences, although none of these individuals participated in the actual survey experiments that are the main focus of this paper. I also interviewed radio hosts that provide public policy programming, and met with various opinion leaders and stakeholders to test out the questions and gauge reactions on the appropriateness of the study questions during in-person settings.

The goal was to understand how best to gain the perspectives of citizens for the purposes of the research. As is the case in such survey methodologies, the goal of the survey treatment was not to present a technical discussion on the complexities of aid in international policy practice (as important as that related topic is, the present research forum simply was not the appropriate channel). The relatively humbler goal was strictly to provide a potential trigger for Ghanaians' own preferences to speak for themselves as much as possible and to thus identify and 
isolate participants' political economy preferences in the context of a relatively simple survey stimulus. News sources such as the Daily Graphic, Ghanaian Times and other newspapers as well as radio stations such as Radio Gold informed the selection of political economy outcome foci.

Although interactions indicated sufficient awareness of political and economic issues to warrant a mobile survey, preferences for development with respect to the area of sanitation, health (malaria), poverty, democracy appeared to receive little engagement according to the stakeholders and citizens. As mentioned earlier, there is little engagement with Ghanaians (and other citizens in developing countries) with respect to international aid and this is the main foundation of this research project. Many Ghanaians said they would be satisfied for their lives to improve slightly, and many felt they "were not asking for much" in the in terms of international development. Many Ghanaians appeared to have low expectations in the area of public policy perhaps due to disillusionment, and this factor appeared to lead many to disengage from policy debates on the above issues in radio. The goal of the study is to see whether a simple survey experiment can help shed light on such apathy, or low levels of preference gravitation using mobile surveys.

VOTO Mobile collects data for client at an average cost of 2 cents to reach a participant. Respondents were free to drop out at any point in time, and in prior work by VOTO Mobile, individuals appeared to be relatively respondent to voice surveys relative to SMS data collection procedures, which is why this paper does not use text messaging. Several radio stations in Ghana have used VOTO Mobile for media and awareness purposes since May 2012 and the platform is one of the most robust and popular in West Africa.

To collect data, VOTO Mobile uploaded recorded audio of the finalized research survey questions in MPEG-1 or MPEG-2 Audio Layer III files (commonly known as "MP3" formats). Individuals listen to the questions in a manner that simulates a small-scale participatory radio program, and respond by speaking into their phones or pressing a number on their phone. About $80 \%$ of users listen to the entire message broadcast, which is unsurprising, given that regular surveys are performed by VOTO Mobile across Ghana for nonprofits, radio stations and other initiatives. The VOTO Mobile system automates the survey process, calling phone numbers from the universe of mobile phones in Ghana for the purposes of surveys with the assistance of mobile network operators while automatically recording the audio and keyed responses which VOTO Mobile arranges into a final spreadsheet automatically. Validity of the results are ensured since the mobile survey experiments were entirely blind so that the author did not have access to the phone numbers of the randomly-selected individuals that answered this survey. The universe under study covered all Ghanaian mobile phone users above the age of 18 years. The treatment survey was performed in September 2014 and the endline was done in October 2014. The project 
focused on the most commonly-spoken languages to allow for a relatively representative survey across the country of Ghana.

\section{Preference Gravity: A Human-Computer Interaction Theory}

The simplified model of humans interacting with their computers (in this case, their mobile phones) is often based on inputs through the human senses and outputs through the motor controls of the effectors (Dix., Finlay, Abowd, \& Beale, 2003). When making physical movements, a stimulus is received through the sensory receptors and transmitted to the brain. After processing, the brain tells the appropriate muscle to respond. I argue that the study participants are attracted to various issues captured by the keyboards of their phones in the mobile survey.

I introduce preference gravity as the degree to which an individual is attracted to alternative choices represented on their mobile phone keyboard. Preference gravity allows one to quantify an intrinsic but objective level of seriousness agents attach to preferences. I frame agents as being drawn to issues in a one-directional relationship between agents and their mobile phone keyboards. A person that gravitates to an issue is defined as one that presses the key on their phone that corresponds to that particular issue when exposed to all available issues. The present framework provides a gravity mechanism within preferences by generalizing the Newtonian metaphors that are familiar to trade and other economists.

Preference gravitation is a network flow. In the simplest possible model, every Ghanaian has a tendency to "move" or "be drawn" toward the "center" of an attractive force of an issue. Each alternative issue exerts its own "pull" on Ghanaians in the model. This is described below as a standard maximum flow problem in a directed acylic network environment where agents are connected to issues by edges.

I let $G=(V, E)$ be a network where $s$ is the source of the network consisting of Ghanaian agents, and $t$ is the sink of the network, representing the issues they are drawn towards. An edge capacity is a mapping $c: E \rightarrow \mathbb{R}$, denoted $c(u, v)$. This refers the maximum flow that can pass through an edge, or degree to which an agent may gravitate towards an issue.

A flow is a mapping $f: E \rightarrow \mathbb{R}$, , denoted by $f(u, v)$, subject to the capacity constraint that the flow of an edge cannot exceed its capacity. This can be represented as a maximum flow problem (Vohra, 2011):

$$
\text { Maximize } \sum_{v:(s, v) \in E} f(u, v)
$$


or to route as much flow as possible from $s$ to $t$, which can, in turn, be thought of as the policy concern of making any many people care about significant issues as feasible.

\subsection{Universal Preference Gravitation}

I assume that an attraction is exerted by every issue on all people. This is what I call a universal preference gravitation. The attraction observed varies by issue, and by individual. The Universal Preference Gravitation assumption means that every issue (including the issue of international aid) can be expected to resonate with individual Ghanaians to some extent. The gravitation towards the following variables may be particularly sensitive to a randomized international aid survey prime, given their low levels of citizen engagement:

- Sanitation: The emergence of the Ebola crisis in West Africa in 2014 did not affect Ghana directly, however main health and environmental concerns in the local radio media appeared to be sanitation and cholera which appeared to have relatively little engagement.

- Poverty Perceptions, Poverty Seriousness and Satisfaction with Poverty Policy in Ghana: A prevalent topic in anecdotal conversations appeared to be the divergence of what many considered to be "real" poverty experiences and objective measures from government sources. This dissatisfaction may account for little engagement from the public on poverty discussions and the subjective experiences and preferences with respect to poverty action may be important.

- Satisfaction with Malaria Policy in Ghana: Malaria remains a significant health concern in Ghana, with relatively low awareness of preventive measures, although many Ghanaians appeared to be aware of imported treatment medicines.

- Ghana's Democracy: Although Ghana is one of the most robust democracies in Africa, there is surprisingly little research on the preferences of Ghanaians for democracy. Some Ghanaians felt that Ghana's democracy was not representative or "focused on the needs of the poor," unlike democracies in other parts of the world.

- The Role of Personal Effort in Success: Another topic that has received little public engagement has been the role of personal effort in economic and social success in Ghana. The preferences of Ghanaians in this respect are understudied. 
Preference gravitation towards the issues of poverty, sanitation, health, politics and individual responsibility are preference mechanisms, so that individuals gravitate towards alternative policy issues to varying degrees that reflect their preferences. I summarize the full process:

1. Each individual Ghanaian gravitates towards a choice set to varying degrees so that the preference gravity reflects a qualitative seriousness that an individual attach to different issues at a point in time.

2. Ghanaians interact with their phone interfaces and press a key that reflects a particular issue they care most about. This represents their revealed preferred topic as an interfacebased preference.

3. Having chosen a topic, Ghanaians self-report a ranking of how important the issue is which represents their stated preferences within the topic.

If the triggering exogenous force is sufficiently strong, it may affect both the human-computer interaction and the self-reported choice.

\section{Experimental Design}

The simple experiment was designed to test how being stimulated to think about international aid, affects how people interact with their phones in terms of choosing different topics to discuss, as well as how people rank the importance of such topics on a simple scale. To understand the political economy of Ghana, I also collect information on various relevant sectors and topics in most relevant areas.

The experiment consistent entirely of a survey treatment question and outcome surveys. No participants completed demographic information surveys, but participants were called at random from across the country. All participants heard general instructions informing them that this was a survey for research purposes, and that they could participate in a raffle for free airtime worth about $\$ 15$. Study participants received no information about their performance until the end of the experiment. Individuals could answer questions at any time of their convenience, and the airtime raffle amount took this into consideration.

In the follow-up for outcome measures, study participants faced questions from an equal number of categories of the political economy of development focusing on the above-mentioned themes of poverty, sanitation, health (malaria), democracy, and the role of personal effort in success.

The simple experiment proceeded as follows. Participants from all over the country are automatically randomized into a "treatment" and "control" group where the treatment group is asked about international aid to Ghana. The control group is not ever exposed to the question of international aid, which they could answer at their leisure. One week later, all participants are 
asked about the political economy of development topics in the endline survey. I describe the experimental design below, which is a basic triple-design study.

\subsection{International Aid Survey Prime}

In the treatment phase of the experiment, VOTO Mobile asks randomized participants throughout Ghana to share their perspective on the state of international aid and development in Ghana. There was no prompting to manipulate participant perception beyond recording the audio responses. Individuals were also asked to rate the effectiveness of Ghana's international aid. In the outcome phase, individuals may choose different topics to engage in. Individuals could answer the questions at any time and provide a ranking, although they had to choose the area. The selection of political economy issues serves as a proxy for the taste, so that the causal impacts of the development aid question explains the generation or production of these tastes.

The outcome phase measured preferences of political economy on an individual basis. Individuals faced six questions, so that a participant could answer any question(s). Individuals could pause the survey and continue at later times, or listen as many times as they wished. Although the rankings elucidate self-reported preferences, the choices of topics that participants choose to answer may, in of themselves parallel the emergent process of the preference a person has for such issues. One can think of a scenario where the degree to which one gravitates toward a particular issue is a signal of how intrinsically important an issue is to a person. This approach mitigates the self-selection-biased issues related to self-reported preferences. In so doing, I provide a revealed preference mechanism without self-reporting that cleanly provides a weaker notion of tastes. By inducing exogenous variation in the form of a treatment question, I am able to isolate how these preferences are produced.

Where one gravitates towards a political economy aspect more consistently and stated preferences significantly change as a result, one can think of a threshold effect where a level of gravitation that exceeds a threshold manifests in strong stated preferences. If self-control and other behavioral problems are salient, then it is feasible that strong intrinsic preferences would motivate individuals to gravitate toward issues they consider important, but would not manifest in strong self-reported preferences for reasons related to inadequate willpower. Although these are complimentary to the paper's approach, self-reported preferences survey responses may be inaccurate, rendering behavioral problems difficult to clearly observe.

The causal preferences consequences of an audio stimulus is best identified by observing the issues individuals are revealed to gravitate towards. One reason for the bias in self-reported preferences with respect to survey experiments is the empirical finding that being surveyed can in of itself affect behavior (Zwane et al, 2011). For this cause, it seems more reasonable to 
minimize the number of surveys performed during a mobile survey impact evaluation: each survey would be a prime unto itself with possible confounding effects that might affect selfreported preferences. Since the VOTO Mobile system is able to achieve true randomness without author manipulation, I do not perform background surveys to isolate socioeconomic and demographic factors, particularly because these may, in of themselves compromise the estimates according to this empirical finding. In Figure 1, I provide a diagram showing the simple survey experimental process.

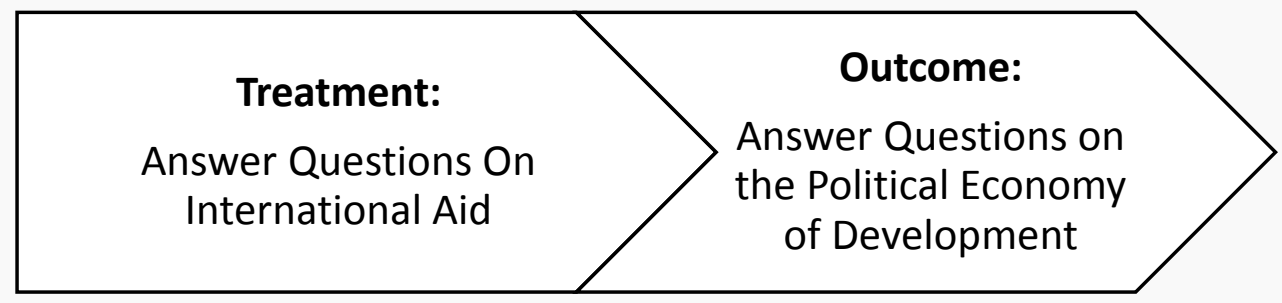

Figure 1 Simple Design of the Experiment

Participants could answer questions in any of the major language families in addition to English: Akan, Hausa, Dagbani, or Ewe. However, from the in-person interviews that wove back and forth across different languages, many Ghanaians are multilingual and it may not realistic to infer much from language choices.

The simple OLS regression is

$$
y_{i}=\alpha+\theta T_{i}+\varepsilon_{i}
$$

where $\alpha$ is a constant term, $T_{i}$ is a dummy variable that equals one if the subject $i$ was asked "what do you think about international aid to Ghana?" and zero if the subject was not asked the treatment question. The dependent variables $y_{i}$ refer to whether the subject $i$ chose to discuss sanitation, poverty, malaria, democracy or personal effort in success as previously defined. The same dependent variable refers to scores subjects gave to their local authorities in addressing these same issues. I estimate the parameter $\theta$ in all cases.

\section{Results}

Table 1 shows descriptive statistics for the study participants. Table I presents the raw data based on the audio surveys; with average responses to questions people answered in general then 
broken down by the survey treatment of whether the person was asked on what they thought about international aid to Ghana. Going forward, I call this question the "international development stimulus" treatment.

Recall that the numbers indicate individuals who chose to respond to the relevant questions (and not their self-reported answers). The differences track the average differences between treatment and control categories. I discuss the empirical approaches in the section.

\section{Table 1: Descriptive Statistics}

\begin{tabular}{|c|c|c|c|}
\hline & $\begin{array}{l}\text { (1) } \\
\mathrm{N}\end{array}$ & $\begin{array}{c}(2) \\
\text { Mean }\end{array}$ & $\begin{array}{c}\text { (3) } \\
\text { Standard } \\
\text { Deviation }\end{array}$ \\
\hline $\begin{array}{l}\text { Panel A: Dummy } \\
\text { Variables (=1) }\end{array}$ & & & \\
\hline $\begin{array}{l}\text { International Aid is } \\
\text { effective }\end{array}$ & 1,761 & 0.269 & 0.444 \\
\hline Happiness & 1,761 & 0.135 & 0.342 \\
\hline Ghana's democracy & 1,761 & 0.176 & 0.381 \\
\hline $\begin{array}{l}\text { Sanitation } \\
\text { Satisfaction }\end{array}$ & 1,761 & 0.128 & 0.334 \\
\hline Effort & 1,761 & 0.148 & 0.355 \\
\hline Malaria & 1,761 & 0.129 & 0.336 \\
\hline $\begin{array}{l}\text { Ghana as Middle } \\
\text { Income }\end{array}$ & 1,761 & 0.169 & 0.375 \\
\hline Lights-Off & 1,761 & 0.129 & 0.336 \\
\hline Poverty Satisfaction & 1,761 & 0.112 & 0.315 \\
\hline Poverty Seriousness & 1,761 & 0.121 & 0.326 \\
\hline Poverty Perception & 1,761 & 0.146 & 0.353 \\
\hline
\end{tabular}




\section{Panel B: Outcome Variables by Treatment and Control Groups}

\begin{tabular}{|c|c|c|c|c|}
\hline Happiness & 474 & $\begin{array}{c}0.205 \\
(0.404)\end{array}$ & 1287 & $\begin{array}{c}0.110 \\
(0.312)\end{array}$ \\
\hline Ghana's democracy & 474 & $\begin{array}{c}0.441 \\
(0.497)\end{array}$ & 1287 & $\begin{array}{c}0.078 \\
(0.270)\end{array}$ \\
\hline Sanitation & 474 & $\begin{array}{c}0.192 \\
(0.394)\end{array}$ & 1287 & $\begin{array}{c}0.104 \\
(0.306)\end{array}$ \\
\hline Effort & 474 & $\begin{array}{c}0.219 \\
(0.414)\end{array}$ & 1287 & $\begin{array}{c}0.121 \\
(0.327)\end{array}$ \\
\hline Poverty Perception & 474 & $\begin{array}{c}0.287 \\
(0.453)\end{array}$ & 1287 & $\begin{array}{c}0.094 \\
(0.292)\end{array}$ \\
\hline Malaria & 474 & $\begin{array}{c}0.192 \\
(0.394)\end{array}$ & 1287 & $\begin{array}{c}0.106 \\
(0.309)\end{array}$ \\
\hline $\begin{array}{l}\text { Ghana as Middle } \\
\text { Income }\end{array}$ & 474 & $\begin{array}{c}0.287 \\
(0.453)\end{array}$ & 1287 & $\begin{array}{c}0.126 \\
(0.332)\end{array}$ \\
\hline Lights-Off & 474 & $\begin{array}{c}0.192 \\
(0.394)\end{array}$ & 1287 & $\begin{array}{c}0.126 \\
(0.332)\end{array}$ \\
\hline Poverty Satisfaction & 474 & $\begin{array}{c}0.162 \\
(0.369)\end{array}$ & 1287 & $\begin{array}{c}0.093 \\
(0.298)\end{array}$ \\
\hline Poverty Seriousness & 474 & $\begin{array}{c}0.181 \\
(0.386)\end{array}$ & 1287 & $\begin{array}{c}0.099 \\
(0.298)\end{array}$ \\
\hline
\end{tabular}

\section{Asked About Aid Not Asked About \\ Aid \\ Asked About Aid Not Asked About}

Notes. The treatment group are people who were asked what they think about international aid. Table 1 shows the outcome variables with means and standard deviations in parentheses.

\subsection{Aid survey stimulus predicts preference gravitation}

I first show that the international development stimulus affects an individual's political economy preference gravitation. In Table 2, I show the impact of the international development stimulus 
treatment on the study participant's decision to discuss topics on the political economy, which is interpreted as preference gravitation.

Each regression (column) includes the treatment and a single outcome in the form of a dummy variable for answering questions on subjective well-being, sanitation, democracy, perceptions of poverty, the importance of personal effort in economic success and health. Being exposed to the development effectiveness discussion has a positive impact on tastes for subjective well-being, poverty, malaria policy and sanitation. What is interesting is that people gravitate to these issues as a result of exposure to development effectiveness to varying degrees, with democracy being the strongest impacted outcome variable. I also consider the impact on the topic of whether or not success in Ghana is due to personal or external efforts. I find that the development discussion has a positive impact on the interface-based preference for personal effort discussions. The effort estimate (39.5\%) is close to that of well-being (40\%), which may imply that Ghanaians consider the potential role of personal effort for success to be nearly the same as subjective well-being in general. Electricity access is the second highest-impacted variable. Interestingly, the topic module that is most significantly impacted by the aid effectiveness discussion is Ghana's democracy. People exposed to the aid effectiveness discussion gravitate the most to discussing the state of Ghanaian political development. This may imply that Ghanaians may consider international development and political development as complimentary. These findings are shown in Table 2.

TABLE 2

AID SURVEY TREATMENT IMPACTS ON INTERFACE-BASED PREFERNCES 
(1)

Variables

Ghana's
(5) Poverty

Democracy
Poverty

Perception
Seriousness
(2)

Sanitation

Satisfaction
(3)

Success in

Ghana is

due to

Personal

Effort

\begin{tabular}{lccccccc} 
Development Aid & $\begin{array}{c}0.362 * * * \\
(0.024)\end{array}$ & $\begin{array}{c}0.193 * * * \\
(0.022)\end{array}$ & $\begin{array}{c}0.069 * * * \\
(0.008)\end{array}$ & $\begin{array}{c}0.089 * * * \\
(0.02)\end{array}$ & $\begin{array}{c}0.098^{* * *} \\
(0.021)\end{array}$ & $\begin{array}{c}0.086 * * * \\
(0.02)\end{array}$ & $\begin{array}{c}0.09 * * * \\
(0.020)\end{array}$ \\
Constant & & & & & & & \\
& $0.078 * * *$ & $0.094^{* * *}$ & $0.093^{* * *}$ & $0.104 * * *$ & $1.121 * * *$ & $0.106 * * *$ & $0.106^{* * * *}$ \\
& $(0.008)$ & $(0.008)$ & $(0.008)$ & $(0.001)$ & $(0.009)$ & $(0.011)$ & $(0.009)$ \\
R-squared & & & & & & & \\
Observations & 0.178 & 0.059 & 0.01 & 0.014 & 0.015 & 0.013 & 0.014 \\
\hline
\end{tabular}

Notes. "Development Aid" is exposure to the randomized survey treatment. Dependent variables represent individuals who chose to discuss Ghana's Democracy ("Ghana's Democracy"), their perception of poverty in Ghana ("Poverty Perception"), how serious they individual thinks poverty is in Ghana ("Poverty Seriousness"), their satisfaction with sanitation measures ("Sanitation Satisfaction"), the degree to which success in Ghana can be achieved by personal effort ("Personal Effort"), their satisfaction with anti-malaria policy ("Malaria Satisfaction"), and how satisfied they are with poverty action policies ("Poverty Satisfaction"). ${ }^{* *}$ denotes $1 \%$, ${ }^{* *}$ denotes $5 \%$, $*$ denotes $10 \%$.

Once the treatment is able to generate or produce interface-based preferences (influencing the pushing of certain buttons), what to these mean for the impact of the randomized treatment on subjective preferences (in the vein of the self-reported scales)? I will show that contrary to much of the social psychology literature on primes and self-reported outcomes, the international aid treatment does not matter for individual self-reported preferences for the political economy topics (in terms of a scale ranking), although they are able to strongly produce inherent tastes for these issues as previously shown. Recall that each participant had to select their highest ranking of every issue as based on their subjective experiences. Interestingly, there are no significant impacts on happiness, sanitation, poverty, malaria, democracy or electricity access satisfaction preferences, although there is a slight positive impact on poverty perception. These results are shown in Table 3. 
TABLE 3

INTERNATIONAL DEVELOPMENT SURVEY TREATMENT IMPACTS ON SUBJECTIVELY-RANKED TASTES AND PREFERNCES

\begin{tabular}{lcccccc}
\hline Variables & $\begin{array}{c}(1) \\
\text { Ghana's } \\
\text { Democracy }\end{array}$ & $\begin{array}{c}(2) \\
\text { Poverty } \\
\text { Perception }\end{array}$ & $\begin{array}{c}(3) \\
\text { Poverty } \\
\text { Seriousness }\end{array}$ & $\begin{array}{c}(4) \\
\text { Sanitation } \\
\text { Satisfaction }\end{array}$ & $\begin{array}{c}(5) \\
\text { Malaria } \\
\text { Satisfaction }\end{array}$ & $\begin{array}{c}(6) \\
\text { Poverty } \\
\text { Satisfaction }\end{array}$ \\
\hline $\begin{array}{l}\text { Development } \\
\text { Aid }\end{array}$ & 0.204 & $0.218^{*}$ & -0.093 & 0.212 & -0.0100 & -0.056 \\
& $(0.167)$ & $(0.131)$ & $(0.088)$ & $(0.160)$ & $(0.151)$ & $(0.153)$ \\
Constant & $3.64 * * *$ & $2.372 * * *$ & $2.717 * * *$ & $4.007 * * *$ & $4.263 * * *$ & $2.927 * * *$ \\
R-squared & $(0.136)$ & $(0.0976)$ & $(0.052)$ & $(0.104)$ & $(0.0894)$ & $(0.094)$ \\
Observations & 0.01 & 0.01 & 0.00 & 0.01 & 0.00 & 0.00 \\
\end{tabular}

Notes. "Development Aid" is exposure to the randomized survey treatment. Dependent variables represent scaled rankings of Ghana's Democracy ("Ghana's Democracy"), their perception of poverty in Ghana ("Poverty Perception"), how serious they individual thinks poverty is in Ghana ("Poverty Seriousness"), their satisfaction with sanitation measures ("Sanitation Satisfaction"), the degree to which success in Ghana can be achieved by personal effort ("Personal Effort"), their satisfaction with anti-malaria policy ("Malaria Satisfaction"), and how satisfied they are with poverty action policies ("Poverty Satisfaction"). *** denotes 1\%, ** denotes 5\%, * denotes 10\%.

In Table 4, I next look at the associations between Ghanaians' view of aid effectiveness and their self-reported preferences for political economy issues. To show that the subjective preferences are important, I next look at the correlations between the responses to the aid question (when looked at as a ranking) and the political economy variables (ranked as discussed above). The correlations between people's subjective rankings of international aid and the political economy of development outcome variables are shown in Table 4. Table 4 shows minor associations between development aid discussions and happiness. Strong correlations between power access and malaria assessments in individual responses may have led to very similar estimates. Again, the state of Ghana's democracy shows the largest correlation. The ability of the treatment to cause selection of specific political economy topics and its inability to affect ranked preferences (ex-post to topic selection) is explained by the ability of the treatment to influence human-computer interactions that, while instructive of the gravitation origins of preferences, may not manifest as impacts on stated or self-reported preferences. 
TABLE 4

AID EFFECTIVENESS ASSOCIATIONS WITH SUBJECTIVELY-RANKED TASTES AND PREFERNCES

\begin{tabular}{|c|c|c|c|c|c|c|}
\hline Variables & $\begin{array}{c}(1) \\
\text { Ghana's } \\
\text { Democracy }\end{array}$ & $\begin{array}{c}(2) \\
\text { Poverty } \\
\text { Perception }\end{array}$ & $\begin{array}{c}(3) \\
\text { Poverty } \\
\text { Seriousness }\end{array}$ & $\begin{array}{c}(4) \\
\text { Sanitation } \\
\text { Satisfaction }\end{array}$ & $\begin{array}{c}(5) \\
\text { Malaria } \\
\text { Satisfaction }\end{array}$ & $\begin{array}{c}(6) \\
\text { Poverty } \\
\text { Satisfaction }\end{array}$ \\
\hline \multirow{2}{*}{$\begin{array}{l}\text { Aid } \\
\text { Effectiveness }\end{array}$} & $0.233 * * *$ & $-0.163 * *$ & 0.084 & 0.0234 & $0.192 * *$ & 0.107 \\
\hline & $(0.0774)$ & $(0.0708)$ & $(0.056)$ & $(0.0962)$ & $(0.0888)$ & $(0.087)$ \\
\hline Constant & $\begin{array}{c}2.941 * * * \\
(0.329)\end{array}$ & $\begin{array}{c}3.228 * * * \\
(0.281)\end{array}$ & $\begin{array}{c}2.138 * * * \\
(0.236)\end{array}$ & $\begin{array}{c}4.133 * * * \\
(0.397)\end{array}$ & $\begin{array}{c}3.543 * * * \\
(0.374)\end{array}$ & $\begin{array}{c}2.476 * * * \\
(0.356)\end{array}$ \\
\hline R-squared & 0.048 & 0.037 & 0.036 & 0.001 & 0.054 & 0.02 \\
\hline Observations & 199 & 134 & 77 & 91 & 91 & 93 \\
\hline
\end{tabular}

Notes. "Aid Effectiveness" is a one to five rating of the effectiveness of development aid in Ghana. Dependent variables represent scaled rankings of Ghana's Democracy ("Ghana's Democracy"), their perception of poverty in Ghana ("Poverty Perception"), how serious they individual thinks poverty is in Ghana ("Poverty Seriousness"), their satisfaction with sanitation measures ("Sanitation Satisfaction"), the degree to which success in Ghana can be achieved by personal effort ("Personal Effort"), their satisfaction with anti-malaria policy ("Malaria Satisfaction"), and how satisfied they are with poverty action policies ("Poverty Satisfaction"). $* * *$ denotes $1 \%$, ** denotes $5 \%$, * denotes $10 \%$.

\subsection{Robustness Checks with KRLS Estimation}

It is entirely plausible that in Generalized Linear Models (such as OLS models used above), the functional form assumptions may not always be appropriate (Leamer, 1983). For example, the marginal effect of each covariate may not be constant across the covariate space. Given that marginal effects in voice mobile surveys may be heterogeneous across units, this could affect both estimation and inference (White, 1980; White, 1981; Wolfgang \& Linton, 1994; Larson \& Bancroft, 1963; Ramsey 1969).

I use the Kernel-Based Regularized Least Squares (KRLS) estimators following (Hainmueller \& Hazlett, 2013) to partly alleviate these concerns. The benefits of the KRLS are as follows: it does not require standard functional form assumptions such as linearity or 
additivity, it minimizes over-fitting, and uses regularization which is attracted to smoother functions relative to erratic ones, potentially reduces the variance and fragility of estimates. The KRLS estimator has helpful statistical properties, such as unbiasedness, consistency, and asymptotic normality under mild regularity conditions (Hainmueller \& Hazlett, 2013). Finally, using KRLS in my experimental setting takes parameter-setting decisions out of the researchers' hands to improve falsifiability.

I check whether the impact of the survey treatment is robust to KRLS estimation. If the underlying functional form assumptions are important, I would expect the survey treatment impact and the randomization process not to survive the relaxing of functional form assumptions. On the other hand, the survey treatment impacts on individuals would overtake any functional form issues if sufficiently robust. I find no evidence that the functional form assumptions affect the results.

TABLE 5

AID EFFECTIVENESS ASSOCIATIONS WITH SUBJECTIVELY-RANKED TASTES AND PREFERNCES

(KERNEL-BASED REGULARIZED LEAST SQUARES)

(5)

Ghana's

Democracy
(3)

Poverty

Perception
(6)

Poverty

Seriousness
(2)

Satisfaction
Sanitation

(4)

Malaria

Satisfacti

on

\begin{tabular}{lcccccc} 
Aid Effectiveness & $0.128 * * *$ & -0.025 & 0.01 & 0.005 & 0.028 & 0.017 \\
& $(0.0444)$ & $(0.031)$ & $(0.012)$ & $(0.02)$ & $(0.026)$ & $(0.0199)$ \\
Observations & 199 & 134 & 77 & 91 & 91 & 93 \\
R-squared & 0.044 & 0.03 & 0.02 & 0.001 & 0.042 & 0.01 \\
\hline
\end{tabular}

Notes. "Aid Effectiveness" is a one to five rating of the effectiveness of development aid in

Ghana. Dependent Variables represent scaled rankings of Ghana's Democracy ("Ghana's

Democracy"), their perception of poverty in Ghana ("Poverty Perception"), how serious they individual thinks poverty is in Ghana ("Poverty Seriousness"), their satisfaction with sanitation measures ("Sanitation Satisfaction"), the degree to which success in Ghana can be achieved by personal effort ("Personal Effort"), their satisfaction with anti-malaria policy ("Malaria Satisfaction"), and how satisfied they are with poverty action policies ("Poverty Satisfaction"). $* * *$ denotes $1 \%$, ** denotes $5 \%$, * denotes $10 \%$.

TABLE 6

INTERNATIONAL DEVELOPMENT SURVEY TREATMENT IMPACTS INTERFACEBASED PREFERENCES

(KERNEL-BASED REGULARIZED LEAST SQUARES) 


\begin{tabular}{lccccccc}
\hline Variables & $\begin{array}{c}(1) \\
\text { Ghana's } \\
\text { Democracy }\end{array}$ & $\begin{array}{c}\text { Poverty } \\
\text { Perception }\end{array}$ & $\begin{array}{c}\text { Poverty } \\
\text { Seriousness }\end{array}$ & $\begin{array}{c}\text { Sanitation } \\
\text { Satisfaction }\end{array}$ & $\begin{array}{c}(5) \\
\text { Success in } \\
\text { Ghana is due } \\
\text { to Personal } \\
\text { Effort }\end{array}$ & $\begin{array}{c}(6) \\
\text { Malaria } \\
\text { Satisfaction }\end{array}$ & $\begin{array}{c}\text { Poverty } \\
\text { Satisfacti } \\
\text { on }\end{array}$ \\
\hline Development & $0.346^{* * *}$ & $0.1719^{* * *}$ & $0.055^{* * *}$ & $0.059^{* * *}$ & $0.075^{* * *}$ & $0.057^{* * * *}$ & $0.060^{* * * *}$ \\
Aid & $(0.025)$ & $(0.0232)$ & $(0.017)$ & $(0.0169)$ & $(0.02)$ & $(0.017)$ & $(0.017)$ \\
Observations & 1761 & 1761 & 1761 & 1761 & 1761 & 1761 & 1761 \\
R-squared & 0.179 & 0.058 & 0.011 & 0.011 & 0.014 & 0.011 & 0.01 \\
\hline
\end{tabular}

Notes. "Development Aid" is exposure to the randomized survey treatment Dependent Variables represent scaled rankings of Ghana's Democracy ("Ghana's Democracy"), their perception of poverty in Ghana ("Poverty Perception"), how serious they individual thinks poverty is in Ghana ("Poverty Seriousness"), their satisfaction with sanitation measures ("Sanitation Satisfaction"), the degree to which success in Ghana can be achieved by personal effort ("Personal Effort"), their satisfaction with anti-malaria policy ("Malaria Satisfaction"), and how satisfied they are with poverty action policies ("Poverty Satisfaction"). ${ }^{* *}$ denotes $1 \%,{ }^{* *}$ denotes $5 \%,{ }^{*}$ denotes $10 \%$.

TABLE 7

INTERNATIONAL DEVELOPMENT SURVEY TREATMENT IMPACTS ON SUBJECTIVELY-RANKED PREFERNCES (KERNEL-BASED REGULARIZED LEAST SQUARES)

\begin{tabular}{|c|c|c|c|c|c|c|}
\hline Variables & $\begin{array}{c}(1) \\
\text { Ghana's } \\
\text { Democracy }\end{array}$ & $\begin{array}{c}(2) \\
\text { Poverty } \\
\text { Perception }\end{array}$ & $\begin{array}{c}(3) \\
\text { Poverty } \\
\text { Seriousness }\end{array}$ & $\begin{array}{c}(4) \\
\text { Sanitation } \\
\text { Satisfaction }\end{array}$ & $\begin{array}{c}(5) \\
\text { Malaria } \\
\text { Satisfaction }\end{array}$ & $\begin{array}{c}6) \\
\text { Poverty } \\
\text { Satisfaction }\end{array}$ \\
\hline \multirow[t]{2}{*}{$\begin{array}{l}\text { Development } \\
\text { Aid }\end{array}$} & 0.12 & 0.133 & -0.051 & 0.118 & -0.006 & -0.031 \\
\hline & $\left(\begin{array}{ll}0 & 139\end{array}\right)$ & $(0.113)$ & $(0.067)$ & $(0.126)$ & $(0.116)$ & $(0.119)$ \\
\hline Observations & 299 & 255 & 197 & 225 & 228 & 230 \\
\hline R-squared & 0.004 & 0.01 & 0.005 & 0.01 & 0.00001 & 0.0005 \\
\hline
\end{tabular}

Notes. "Development Aid" is exposure to the randomized survey treatment. Dependent Variables represent scaled rankings of Ghana's Democracy ("Ghana's Democracy"), their perception of poverty in Ghana ("Poverty Perception"), how serious they individual thinks poverty is in Ghana ("Poverty Seriousness"), their satisfaction with sanitation measures ("Sanitation Satisfaction"), the degree to which success in Ghana can be achieved by personal effort ("Personal Effort"), their satisfaction with anti-malaria policy ("Malaria Satisfaction"), and how satisfied they are with poverty action policies ("Poverty Satisfaction"). *** denotes $1 \%,{ }^{* *}$ denotes $5 \%,{ }^{*}$ denotes $10 \%$. 


\subsection{Preferences for Pro-Poor Policies}

In this section, I ask whether the international aid stimulus has any consequences on pro-poor policy preferences. It is possible that talking about international aid may nudge participants to be relatively empathetic, so that subjects gravitate toward discussing pro-policies more and perhaps have stronger self-reported preferences for policies that are aimed at alleviating poverty. On the other hand, discussing international aid may have no bearing.

I find significant impacts of the survey treatment on the willingness to discuss as well as the self-reported preferences for pro-poor policies. Individuals are significantly more willing to discuss pro-poor policies due to the international aid survey stimulus. One interesting result is that participants report higher support for pro-poor policies, while others show agreement with less support for pro-poor policies. However, the impact on the support for pro-poor policies is strongest. It is important to note that the survey did not specify what these pro-poor policies would actually be. Before one can extrapolate to public policy, more research is needed on linking the tastes individuals have with actual aid received in-country at the macroeconomic and microeconomic levels.

TABLE 8

DEVELOPMENT AID SURVEY AND EMPATHY PREFERENCE IMPACTS AND
ASSOCIATIONS:
AGREEING (DISAGREEING) WITH PRO-POOR POLICY

(1)

(2)

(3)

(4)

(5)

(6)

\begin{tabular}{|c|c|c|c|c|c|c|}
\hline Variables & $\begin{array}{l}\text { Govt spend } \\
\text { aid } \\
\text { (OLS) }\end{array}$ & $\begin{array}{c}\text { Govt spend } \\
\text { aid } \\
\text { (Agree) } \\
\text { (OLS) }\end{array}$ & $\begin{array}{c}\text { Govt spend } \\
\text { aid } \\
\text { (Disagree) } \\
\text { (OLS) }\end{array}$ & $\begin{array}{c}\text { Govt spend } \\
\text { aid } \\
\text { (KRLS) }\end{array}$ & $\begin{array}{c}\text { Govt spend } \\
\text { aid } \\
\text { (Agree) } \\
\text { (KRLS) }\end{array}$ & $\begin{array}{c}\text { Govt spend } \\
\text { aid (Disagree) } \\
\text { (KRLS) }\end{array}$ \\
\hline $\begin{array}{l}\text { Development } \\
\text { Aid }\end{array}$ & $0.101 * * *$ & $0.067 * * *$ & $0.03^{* * *}$ & $0.077 * * *$ & $0.044 * * *$ & $0.02 * *$ \\
\hline Constant & $\begin{array}{c}(0.021) \\
0.118 * * * \\
(0.009)\end{array}$ & $\begin{array}{c}(0.017) \\
0.072 * * * \\
(0.007)\end{array}$ & $\begin{array}{c}(0.011) \\
0.018^{* * *} * \\
(0.004)\end{array}$ & $(0.02)$ & $(0.146)$ & (0.008) \\
\hline $\begin{array}{l}\text { Observations } \\
\text { R-squared }\end{array}$ & $\begin{array}{c}1761 \\
0.016 \\
\end{array}$ & $\begin{array}{c}1761 \\
0.01 \\
\end{array}$ & $\begin{array}{c}1761 \\
0.011\end{array}$ & $\begin{array}{l}1761 \\
0.007\end{array}$ & $\begin{array}{l}1761 \\
0.01\end{array}$ & $\begin{array}{c}1761 \\
0.006\end{array}$ \\
\hline
\end{tabular}

Notes. "Development Aid" is a mobile survey experiment treatment of a development aid question in Ghana. The first three columns represent OLS estimates and the last three represent KRLS estimates. Dependent Variables represent whether an individual chose to discuss how the government should aid the poor, their ranking of whether they agree with government aiding the 
poor, and their ranking of whether they disagree with government aiding the poor. $* * *$ denotes $1 \%$, ** denotes $5 \%$, * denotes $10 \%$.

\subsection{Preferences for Subjective Well-being}

In this section, I ask whether mobile survey responses on happiness react to the international aid treatment survey. Participants self-reported how happy they were during the survey. Of course, given my previous discussion, the results on tastes for subjective well-being (the desire to discuss happiness) may not be the same as the ranked preference for happiness.

For some Ghanaians, the recent emergence of the country as growing economic power on the African continent seemed to jar with a lack of "enjoyment" or what might be labelled subjective well-being. In in-person interviews (not conducted over phones), some Ghanaians felt that "figures" (informal shorthand for objective measures of development such as Gross Domestic Product per capita or the Human Development Index) did not reflect "in their personal lives." The goal of this section is to see whether Ghanaians gravitate to happiness as a topic following the survey treatment prime.

My results show that being primed to think about international aid, which may induce thoughts of altruism, affects the willingness to discuss happiness, but only marginally affects self-reported happiness. effect of the survey treatment on the desire to discuss happiness, or the production of happiness tastes are about 7\%. The survey treatment does not affect the ranked preferences of happiness, however. There are no significant associations between the continuous measure of the survey treatment and happiness as a self-reported preference.

TABLE 9

DEVELOPMENT AID SURVEY AND HAPPINESS PREFERENCE IMPACTS WITH RESULTS ON AID EFFECTIVENESS AND SELF-REPORTED HAPPINESS ASSOCIATIONS 


\begin{tabular}{lcccc}
\hline Variables & $\begin{array}{c}(1) \\
\text { Happiness } \\
\text { (OLS) }\end{array}$ & $\begin{array}{c}(2) \\
\text { Happiness } \\
\text { (OLS, } \\
\text { continuous) }\end{array}$ & $\begin{array}{c}(3) \\
\text { Happiness } \\
\text { (KRLS) }\end{array}$ & $\begin{array}{c}(4) \\
\text { Happiness } \\
\text { (KRLS, } \\
\text { continuous) }\end{array}$ \\
\hline Development Aid & $\begin{array}{c}0.095^{* * *} \\
(0.02)\end{array}$ & $\begin{array}{c}0.169 \\
(0.162)\end{array}$ & $\begin{array}{c}0.072 * * * \\
(0.0197)\end{array}$ & 0.093 \\
Constant & $0.11^{* * *}$ & $3.936^{* * *}$ & & \\
& $(0.009)$ & $(0.103)$ & & \\
Observations & 1761 & 238 & 1761 & 238 \\
R-squared & 0.02 & 0.004 & 0.014 & 0.014 \\
\hline
\end{tabular}

\begin{tabular}{lcc}
\hline Variables & $\begin{array}{c}(5) \\
\text { Happiness } \\
\text { (Ranking) } \\
(\text { OLS) }\end{array}$ & $\begin{array}{c}(6) \\
\text { Happiness } \\
\text { (Ranking) } \\
\text { (KRLS) }\end{array}$ \\
\hline Aid Effectiveness & $0.202^{*}$ & 0.066 \\
& $(0.017)$ & $(0.007)$ \\
Constant & $3.36^{* * *}$ & \\
& $(0.441)$ & \\
Observations & 97 & 97 \\
R-squared & 0.05 & 0.1 \\
\hline
\end{tabular}

Notes. "ID: International Development" is a mobile survey experiment treatment of a development aid question in Ghana. The Table shows both OLS and KRLS estimates. Dependent Variables represent whether an individual chose to discuss happiness, their ranking of how happy they were during the mobile survey, and regression estimates showing correlations between self-reported aid effectiveness and happiness. $* * *$ denotes $1 \%$, ** denotes $5 \%$, * denotes $10 \%$.

\section{Discussion and Conclusion}

By focusing on purely random voice-based surveys in local languages, I am not only motivating tastes from relatively educated individuals or from wealthier, more educated, younger Ghanaian households, both of which may tend to be favored by text based surveys in exclusively foreign languages such as English or French. By allowing individuals to complete the surveys at any time of their convenience, I am also able to mitigate the issue of encouraging contributions from participants that are most easy to access that may be better off in terms of subjective well-being (Heffetz and Rabin, 2013). Although economists often consider financial policies when 
conceptualizing international aid, many citizens in host countries such as Ghana tend think of aid in much broader terms based on things more directly observed: the activities of private citizens, non-governmental organizations, tourists, or even study-abroad students or visiting faculty doing fieldwork.

The tastes and preferences citizens have for the political economy of development process are important for understanding the development process in any country, and how these tastes are produced may be important for policy makers. This finding of topic association that fall short of stated preferences may simply be a self-control problem of sorts. That is, perhaps Ghanaians identify with the topic of international aid strongly, but not significantly enough for this resonance to affect preferences. It is interesting to note that the topics resonate to varying degrees with democracy being the strongest. Perhaps a commitment that emphasizes democracy may be relevant for broadening the international aid discourse and making discussions more inclusive. To the best of my knowledge, this paper is the first to use a mobile survey to isolate the tastes for development, taking full advantage of the near-comprehensive mobile phone access (World Bank, 2017). However, I must note that the easy availability of mobile phones and mobile surveys however, should not be understood to render in-country fieldwork irrelevant. The research and findings are fuelled by significant field work to provide context.

A primary concern in survey experiments is simulating the randomization process, given the finding in the literature that being surveyed does, in of itself affect behavior and related outcomes. This hurdle motivated my use of a computerized system that blindly randomizes and gains national representativeness was to sidestep the need for multiple surveys to isolate background variables which would have introduced bias. In fact, my results imply that the impact of mobile surveys on preferences may not be generally as severe as the literature had previously suggested. On the other hand, I find that raising the issue of development effectiveness and aid among Ghanaians means that respondents develop preferences for discussing subjective development issues to varying degrees. Given the simplicity of the experiment, the use of a complementary machine learning approach helps show that the findings are relatively robust.

The findings have resonance for timely on the role of international aid in fighting poverty. Electronic governance is emerging as a way to support the Sustainable Development Goals (Opoku-Agyemang, 2015, United Nations, 2016), although the replication crisis implies that using self-reported preferences may not always be reliable in understanding how to achieve them from a behavioral and social-psychological standpoint. Perhaps international development and aid discussions may be able to include automated research approaches over time. However, critical issues such as privacy, require further discussions with citizens before such approaches can be embedded into public policy. 


\section{References}

1. Acemoglu, D., \& Robinson, J. (2012). Why Nations Fail: The Origins of Power, Prosperity and Poverty. New York: Crown Business.

2. Aker, J. C., Ghosh, I. \& Burrell, J. (2016). The promise (and pitfalls) of ICT for agriculture initiatives. Agricultural Economics, 47, 35-48.

3. Angrist, J. D., \& Pischke, J-S. (2010). The Credibility Revolution in Empirical Economics: How Better Research Design Is Taking the Con out of Econometrics. Journal of Economic Perspectives, 24(2), 3-30.

4. Athey, S. (2017). Beyond prediction: Using big data for policy problems. Science, 355(6324), 483-485.

5. Bartling, B., Fehr. E., \& Herz, H. (2014). The Intrinsic Value of Decision Rights. Econometrica, 82(6), 2005-2039.

6. Bauernschuster, S., Falck, O., \& Woessmann, L. (2014). Surfing Alone? The Internet and Social Capital: Evidence from an Unforeseeable Technological Mistake. Journal of Public Economics, 117, 73-89.

7. Blumenstock, J. E., Cadamuro, G., \& On, R. (2015). Predicting Poverty and Wealth from Mobile Phone Metadata. Science, 350(6264), 1073-1076.

8. Bose, S., \& Renou, L. (2014). Mechanism Design with Ambiguous Communication Devices. Econometrica 82(5), 1853-1872.

9. Brickman, P., \& Campbell, D., (1971). Hedonic Relativism and Planning the Good Society. In M. H. Appley (Ed). Adaptation Level Theory: A Symposium. (pp. 287-302). New York: Academic Press.

10. Bruhn, M., \& McKenzie, D. (2009). In Pursuit of Balance: Randomization in Practice in Development Field Experiments. American Economic Journal: Applied Economics, 1(4), 200-232. 
11. Camerer, C.F., Dreber, A., Forsell, E., Ho, T., Huber, J., Johannesson, M., Kirchler, M., Almenberg, J., Altmejd, A., Chan, T., \& Heikensten, E. (2016). Evaluating replicability of laboratory experiments in economics. Science, 351(6280), 1433-1436.

12. Casey, K., Glennerster, R., \& Miguel, E. (2012). Reshaping Institutions: Evidence on Aid Impacts Using a Preanalysis Plan. Quarterly Journal of Economics, 127(4), 1755-1812.

13. Cason, T. N., \& Plott, C. R. (2014). Misconceptions and Game Form Recognition: Challenges to Theories of Revealed Preference and Framing. Journal of Political Economy, 122(6), 1235-1270.

14. Cesario, J. (2014). Priming, replication, and the hardest science. Perspectives on Psychological Science 9(1), 40-48.

15. Dix, A., Finlay, J. E., Abowd, G., \& Beale, R. (2003). Human-Computer Interaction, 3rd Edition. Essex, England: Prentice Hall.

16. Donaldson, D. (2017). "Railroads of the Raj: Estimating the impact of transportation infrastructure." American Economic Review, forthcoming.

17. Downs, A. (1957). An economic theory of political action in a democracy. Journal of Political Economy, 65(2), 135-150.

18. Easterlin, R. A. (1974). Does Economic Growth Improve the Human Lot? In P. A. David \& M. W. Reder (Eds). Nations and Households in Economic Growth: Essays in Honour of Moses Abramovitz (pp. 89-125). New York: Academic Press.

19. Easterly, W. R. (2001). The Elusive Quest for Growth: Economists'Adventures and Misadventures in the Tropics. Cambridge: MIT Press.

20. Easterly, W. R. (2001). The White Man's Burden: Why the West's Efforts to Aid the Rest have Done so Much Ill and so Little Good. New York: Penguin.

21. Einav, L. \& Levin, J. (2014). Economics in The Age of Big Data. Science, 346(6210), 715.

22. Findley, M. G., Harris, A. S., Milner, H. V., \& Nielson, D. (2015). Elite and Mass Support for Foreign Aid Versus Government Programs: Experimental Evidence from Uganda. Mimeo, Princeton University. 
23. Gul, F., \& Pesendorfer, W. (2001). Temptation and Self-Control. Econometrica, 69(6), 1403-1435.

24. Gyimah-Boadi, E. (2009). Another Step forward for Ghana. Journal of Democracy 20(2), 138-152.

25. Hainmueller, J., \& Hazlett, C.(2013). Kernel Regularized Least Squares: Reducing Misspecification Bias with a Flexible and Interpretable Machine Learning Approach. Political Analysis, 22(2), 143-168.

26. Wolfgang, H., \& Linton, O. (1994). Applied Nonparametric Methods. Handbook of Econometrics, 4, 2295-2339.

27. Harris, C. R., Coburn, N., Rohrer, D., \& Pashler, H. (2013). Two failures to replicate high-performance-goal priming effects. PloS one, 8(8), e72467.

28. Heffetz, O., \& Rabin, M. (1998). Conclusions Regarding Cross-Group Differences in Happiness Depend on Difficulty of Reaching Respondents. American Economic Review, 103(7), 3001-3021.

29. Holland, J., Blackburn, J. \& Chambers, R. (1998). Whose Voice? Participatory Research and Policy Change (Intermediate Technology Publications in Participation Series). London: Intermediate Technology Publications.

30. Ioannidis, J. (2005). Why most published research findings are false. PLoS Medicine, 2(8), 0696-0701.

31. Johnson, C. (2001). Local democracy, democratic decentralisation and rural development: theories, challenges and options for policy. Development Policy Review, 19(4), 521-532.

32. Kimball, Miles (2015). Cognitive Economics. National Bureau of Economic Research Working Paper 20834.

33. Kuziemko, I., Norton, M., Saez, E., \& Stantcheva, S. (2015). How Elastic are Preferences for Redistribution: Evidence from Randomized Survey Experiments. American Economic Review, 105(4), 1478-1508. 
34. Laibson, D. (1997). Golden Eggs and Hyperbolic Discounting. Quarterly Journal of Economics, 112(2), 443-477.

35. Laitin, D., \& Wildavsky, A. (1988). Political Culture and Political Preferences. American Political Science Review, 82(02), 589-597.

36. Larson, H. J. \& Bancroft, T. A. (1963). Sequential Model Building for Prediction in Regression Analysis, I. Annals of Mathematical Statistics, 34(2), 462-479.

37. Leamer, E. (1983). Taking the Con out of Econometrics. American Economic Review, $73(1), 31-43$.

38. Leo, B., Morello, R. Mellon, J., Peixoto, T., \& Davenport, S. (2015). Do Mobile Phone Surveys Work in Poor Countries? Center for Global Development Working Paper 398.

39. Li, T. M. (2007), The Will to Improve: Governmentality, Development, and the Practice of Politics. Durham: Duke University Press.

40. Lyubomirsky, S., Sheldon, K., \& Schkade, D. (2005). Pursuing Happiness: The Architecture of Sustainable Change. Review of General Psychology 9(2), 1-47.

41. Mani, A., Mullainathan, S., Shafir, E., \& Zhao, J. (2013). Poverty Impedes Cognitive Function. Science, 341(6149), 976-980.

42. Mayda, A. M. (2010). International migration: a panel data analysis of the determinants of bilateral flows. Journal of Population Economics, 23(4), 1249-1274.

43. Miguel, E., Camerer, C., Casey, K., Cohen, J., Esterling, K., Gerber, A., Glennerster, R., Green, D., Humphreys, M., Imbens, G., Laitin, D., Madon, T., Nelson, L., Nosek, B., Petersen, M., Sedlmayr, R., Simmons, J., Simonsohn, U. \& Van der Laan, M. (2014). Promoting transparency in social science research. Science, 343(6166), 30-31.

44. Mitchell, Timothy (2002). Rule of Experts: Egypt, Techno-Politics, Modernity. Berkeley: University of California Press.

45. Niven, K., Totterdell, P., Holman, D. \& Headley, T. (2012). Does Regulating Others' Feelings Influence People's Own Affective Well-Being? Journal of Social Psychology, 152(2), 246-260. 
46. Nosek, B. A., Alter, G., Banks, G., Borsboom, D., Bowman, S., Breckler, S., Buck, S., Chambers, S., Chin, G., Christensen, G., Contestabile, M., Dafoe, A., Eich, E., Freese, J., Glennerster, R., Goroff, D., Green, D. P., Hesse, B., Humphreys, M., Ishiyama, J., Karlan, D., Kraut, A.,Lupia, A., Mabry, P., Madon, T., Malhotra, N., Mayo-Wilson, E., McNutt, M., Miguel, E.. Paluck, E., Simonsohn, U., Soderberg, C., Spellman, B., Turitto, J., VandenBos, G., Vazire, S., Wagenmakers, E., Wilson, R., \& Yarkoni, T. (2015). Promoting an open research culture. Science, 348(6242), 1422-1425.

47. Nunn, N. \& Qian, N. (2014). U.S. Food Aid and Civil Conflict. American Economic Review, 104(6), 1630-1666.

48. Ok, E.., Ortoleva, P., \& Riella, G. (2015). Revealed (P)reference Theory. American Economic Review 105(1), 299-321.

49. Opoku-Agyemang, K (2015). Mobilizing Impact Evaluations: Mobile Survey MicroExperiments for Sustainable Development. Evaluation Matters, Emerging Solutions to Development Challenges Vol. 1. (pp. 24-29). Abidjan, Cote d'Ivoire: African Development Bank.

50. Phelps, E., \& Pollak, P. (1968). On Second-best National Saving and Game-Equilibrium Growth. Review of Economic Studies 35(2), 185-199.

51. Posard, M. N. \& Rinderknecht, R. G. (2015). Do People Like Working with Computers More than Human Beings? Computers in Human Behavior, 51, 232-238.

52. Qian, N. (2015). Making Progress on Foreign Aid. Annual. Review of Economics, 7(1), 277-308.

53. Ramsey, J. B. (1969). Tests for Specification Errors in Classical Linear Least-Squares Regression Analysis. Journal of the Royal Statistical Society. Series B (Methodological), 31(2), 350-371.

54. Sachs, J. (2006). The End of Poverty: Economic Possibilities For Our Time. New York: Penguin.

55. Taylor, Marilyn (2011). Public policy in the community. New York: Palgrave Macmillan.

56. Tomlinson, M., Solomon, W., Singh, Y., Doherty, T., Chopra, M., Ijumba, P., Tsai, A., \& Jackson, D. (2009). The Use of Mobile Phones as a Data Collection Tool: A Report From 
a Household Survey in South Africa. BMC Medical Informatics and Decision Making 9, $1-8$.

57. United Nations (2016). United Nations E-Government Survey 2016: E-Government in Support of Sustainable Development. http://workspace.unpan.org/sites/Internet/Documents/UNPAN96407.pdf

58. Varian, H. (2014). Big Data: New Tricks for Econometrics. Journal of Economic Perspectives, 28(2), 3-27.

59. Vohra, R. (2011). Mechanism Design: A Linear Programming Approach. New York: Cambridge University Press.

60. VOTO Mobile (2014). VOTO Mobile. http://www.votomobile.org

61. White, H. (1980). A Heteroskedasticity-Consistent Covariance Matrix and a Direct Test for Heteroskedasticity. Econometrica 48(4), 817-838.

62. White H. (1981). Consequences and Detection of Misspecified Nonlinear Regression Models. Journal of the American Statistical Association, 76(374), 419-433.

63. World Bank, "Mobile Cellular Subscriptions (Per 100 People)" http://data.worldbank.org/indicator/IT.CEL.SETS.P2/countries/1W?display=default

64. Zwane, A., Zinman, J., Van Dusen, E. Pariente, W., Null, C., Miguel, E., Kremer, M., Karlan, D., Hornbeck, R., Gine, X., Duo, E., Devoto, F., Crepon, B., \& Banerjee, A. (2011). The Risk of Asking: Being Surveyed Can Aect Later Behavior. Proceedings of the National Academy of Sciences 108, 1821-1826. 